\title{
The role of klotho in chronic kidney disease
}

\author{
Di Zou', Wen Wu², Yan $\mathrm{He}^{1}$, Sichao $\mathrm{Ma}^{1}$ and Ji Gao ${ }^{3 *}$
}

\begin{abstract}
Chronic kidney disease (CKD) is an inherently systemic disease that refers to a long-term loss of kidney function. The progression of CKD has repercussions for other organs, leading to many kinds of extrarenal complications. Intensive studies are now being undertaken to reveal the risk factors and pathophysiological mechanism of this disease. During the past 20 years, increasing evidence from clinical and basic studies has indicated that klotho, which was initially known as an anti-aging gene and is mainly expressed in the kidney, is significantly correlated with the development and progression of CKD and its complications. Here, we discuss in detail the role and pathophysiological implications of klotho in ion disorders, the inflammation response, vascular calcification, mineral bone disorders, and renal fibrosis in CKD. Based on the pathogenic mechanism of klotho deficiency and klotho decline in urine early in CKD stage 2 and even earlier in CKD stage 1, it is not difficult to understand that soluble klotho can serve as an early and sensitive marker of CKD. Moreover, the prevention of klotho decline by several mechanisms can attenuate renal injuries, retard CKD progression, ameliorate extrarenal complications, and improve renal function. In this review, we focus on the functions and pathophysiological implications of klotho in CKD and its extrarenal complications as well as its potential applications as a diagnostic and/or prognostic biomarker for CKD and as a novel treatment strategy to improve and decrease the burden of comorbidity in CKD.
\end{abstract}

Keywords: Chronic kidney disease, Extrarenal complications, Klotho functions, Pathogenic mechanism, Potential applications

\section{Background}

Chronic kidney disease (CKD) is a progressive systemic disease that irreversibly alters the function and structure of the kidney, over months or years. CKD progression has repercussions for other organs, exerting multiple negative systemic effects on numerous organs, including those of the cardiovascular system, leading to cardiovascular diseases, which increase the risk of mortality [1]. In the past 3 decades, Intensive studies in animals and humans have been performed to reveal the risk factors and pathophysiological mechanism of this disease. These studies have established that the original disease process causes an initial loss of nephron unit; then, renal diseases progress to renal failure as a consequence of functional adaptations intervening in the kidney, leading to injury in other organs. Moreover, many factors are involved in this process, including a variety of cytokines, growth factors and vasoactive substances [2,3]. Recently,

\footnotetext{
* Correspondence: gaoji20170729@sina.com

${ }^{3}$ Department of Urology, China-Japan Union Hospital, Jilin University,

Changchun, Jilin 130000, China

Full list of author information is available at the end of the article
}

more evidences has suggested that the development and progression of CKD are significantly associated with a decline in klotho, which was initially described as an anti-aging gene [4-7].

The klotho gene is mainly expressed in the cell surface membrane of proximal and distal renal tubules [8-12]. Uder normal physiological conditions, the kidney is a major regulator that helps maintain klotho levels $[6,13$, 14]. However, in individuals and in animal models with CKD, klotho levels decline and are accompanied by renal insufficiency [7, 15]. Experimentally, klotho-deficient mice and CKD subjects have similar phenotypes, suggesting that klotho is tightly correlated with the pathogenic mechanism of CKD [4, 7]. Furthermore, further evidence has shown that klotho is not only an early biomarker of CKD, but also a potential therapeutic target for CKD $[14,16,17]$. Thus, based on the relationship between klotho and CKD, we here systematically review the functions, physiopathological characteristics, and potential applications of klotho in the related signs and complications of CKD. 


\section{Main text}

\section{The klotho family and structure}

Klotho family members include $\alpha-, \beta-$, and $\gamma$-klotho genes based on their predicted primary sequences $[18,19]$. $\beta$ - and $\gamma$-klotho were discovered based on their homology with $\alpha$-klotho, and they all share a single-pass transmembrane protein $[20,21]$. $\beta$-Klotho is predominantly expressed in the liver but is also found in the kidney, gut, and spleen and mediates the activity of members of the fibroblast growth factor (FGF) family, such as FGF-19 and -21 [18, 22]. $\gamma$-Klotho is expressed in the kidney and skin and has undefined functions $[18,21]$. In this review, we only focus on $\alpha$-klotho; the term klotho in the following paragraphs refers to $\alpha$-klotho.

$\alpha$-Klotho is composed of five exons that correspond 1,012 amino acids in the human protein and 1,014 amino acids in the mouse protein (Fig. 1a) [23]. The protein consists of a large extracellular domain, including 980 $\mathrm{N}$-terminal residues followed by a 21 -amino-acid transmembrane domain and a small domain of 11 residues corresponding to the intracellular C-terminus [10, 24]. The extracellular domain of membrane klotho consists of two repeat sequences of 440 amino acids termed $\mathrm{Kl} 1$ and $\mathrm{Kl} 2$, which are generated by full-length transcript splicing and can be cleaved by the metalloproteinases ADAM-10 and ADAM-17 and released into circulation as soluble klotho (cleaved klotho) (Fig. 1b) [10, 25-27]. In addition, an alternatively spliced klotho mRNA transcript has been hypothesized to code for a secreted klotho protein, which would equate to the Kl1 domain, but this putative protein has not been identified and has not been detected in human serum thus far; it has been observed only in in vitro systems $[24,28,29]$. Furthermore, a recent study showed that this alternative klotho mRNA was degraded by nonsensemediated mRNA decay (NMD), finally resulting in no active protein translation [30]. Soluble klotho is the main functional form in the circulation $[1,31]$ and is detected in the blood, urine, and cerebrospinal fluid [31-34], exerting its function by acting as a hormone. Additionally, another functional form of klotho occurs, termed membrane-bound klotho, which is mainly involved in FGF receptor signalling.

\section{The function and pathophysiological implications of klotho in CKD \\ Co-receptor of FGF23}

FGF23 belongs to the FGF family. Many studies have shown that FGF23 not only increases the urinary excretion

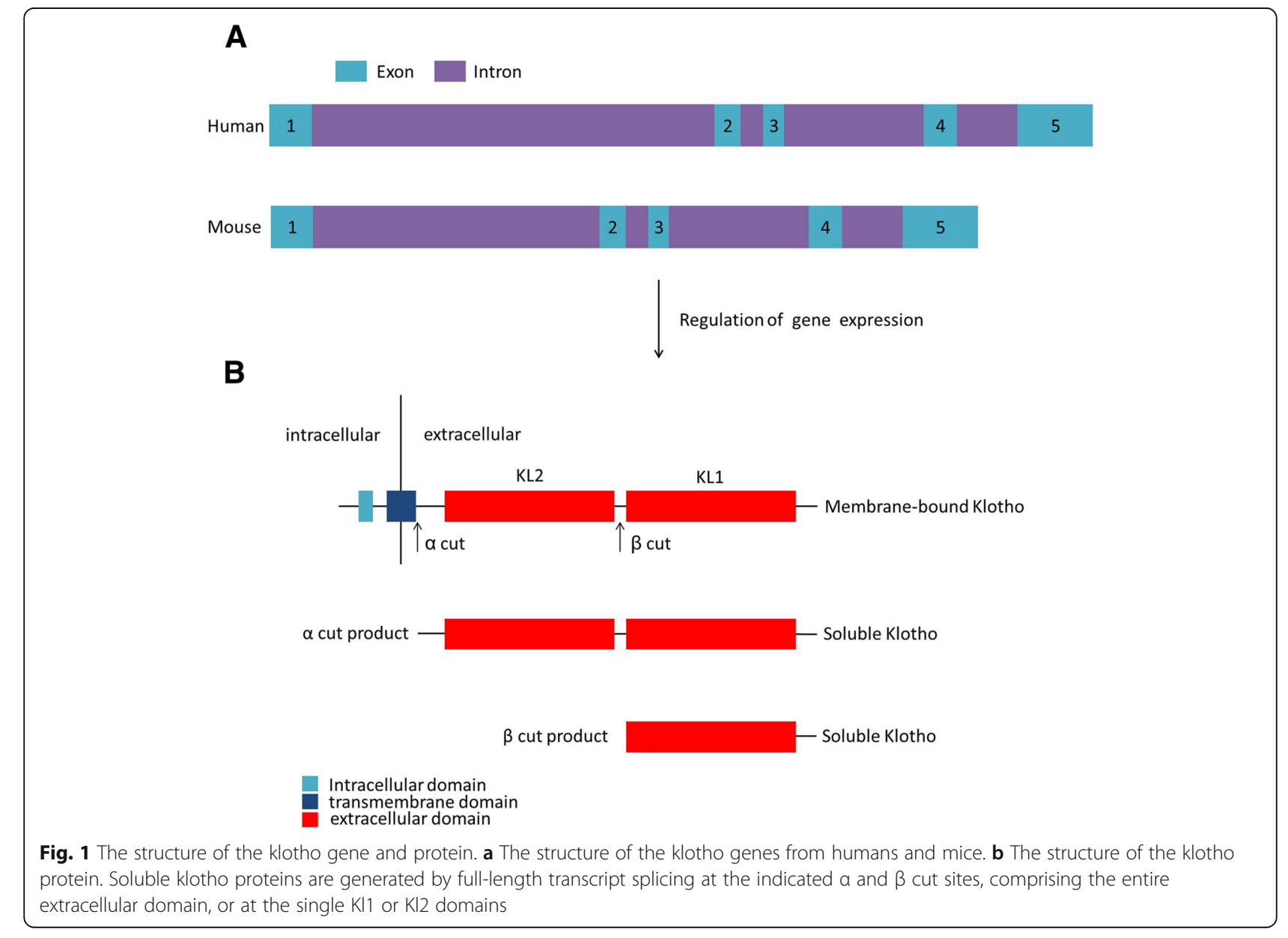


of phosphate but also indirectly suppresses intestinal phosphate absorption by down-regulating the production of $1 \alpha, 25$-dihydroxyvitamin D3 $\left(1,25(\mathrm{OH})_{2} \mathrm{D}\right) \quad[12,35-37]$. FGF23 transduces signals by binding to its receptors to phosphorylate downstream signalling molecules [38]. There are four different FGF receptors (FGFRs), FGFR1-4; these proteins are tyrosine kinase receptors and have high or low affinity for FGFs. Because of their lack of a heparan sulfate-binding domain, FGF23 requires full-length klotho to convert the canonical FGFR into a specific high-affinity receptor to function in target tissues [39, 40]. Recently, research has shown that in the complex consisting of the shed extracellular domain of klotho, the FGFR1c ligandbinding domain, and FGF23, klotho simultaneously tethers FGFR1c by its D3 domain and FGF23 by its C-terminal tail, thus resulting in FGF23-FGFR1c proximity and conferring stability [41]. Thus, klotho is an essential co-receptor for the binding of FGF23 to its receptors.

In proximal renal tubules, blood-borne FGF23 binds to FGFR-klotho complexes and directly activates extracellular signal-regulated kinase (ERK) $1 / 2$ and serum/glucocorticoid-regulated kinase (SGK)-1 signals. Subsequently, SGK-1 phosphorylates the $\mathrm{Na}^{+} / \mathrm{H}^{+}$exchange regulatory cofactor (NHERF)-1 to down-regulate membrane expression of the key sodium phosphate cotransporter NaPi-2a, thus leading to an increase in urinary phosphate excretion [12, 42-44]. Loss of membrane-bound klotho expression limits FGF23stimulated signal transduction through FGFR-klotho complexes. It has been shown that a specific deletion of klotho in proximal renal tubules was unable to increase renal phosphate excretion in vivo [45], suggesting that the effect of FGF23 on phosphate excretion is limited by proximal tubular klotho deficiency. Furthermore, FGF23 suppresses renal $1 \alpha$-hydroxylase expression, which is the key enzyme responsible for $1,25(\mathrm{OH})_{2} \mathrm{D}$ production, by a klothodependent signalling mechanism in proximal renal tubules [46-48]. In addition, soluble klotho directly regulates phosphorus excretion in the kidney and participates in systemic mineral homeostasis by regulating $1 \alpha$-hydroxylase activity and parathyroid hormone (PTH) and FGF23 secretion [49, 50]. These results suggest that klotho deficiency limits its regulation of FGF23 production and hyperphosphataemia remains the principal regulator of FGF23 secretion in CKD [51]. The effect of FGF23 on both phosphate and $1,25(\mathrm{OH})_{2} \mathrm{D}$ is involved in FGFR1, FGFR3, and FGFR4, especially FGFR1 $[52,53]$. In addition, it has been identified that as with the mineral parameters, FGF23 and phosphate are increased, while klotho and $1,25(\mathrm{OH})_{2} \mathrm{D}$ are decreased in CKD, especially in early stages, except serum phosphate [54-56]. These changes in mineral parameters play a central role in the pathophysiology of CKD [19]. Notably, each disturbance in the mineral parameters can be pathogenic alone or can drive and exaggerate the disturbance of the other parameters $[18,19]$.
It was previously reported that soluble klotho is a regulator of the epithelial calcium channel transient receptor potential vannilloid-5 (TRPV5), a glycoprotein that is essential for the entry of calcium into calcium-transporting renal epithelial cells [57]. TRPV5 regulation by klotho is thought to operate as follows: soluble klotho specifically hydrolyses sugar residues from the glycan chains on TRPV5, which in turn stabilizes TRPV5 in the membrane through interaction of the sugar residues with extracellular galectin [57, 58]. However, the cellular secretion process of klotho is unclear. Recently, a decrease in renal calcium reabsorption and a renal membrane abundance of TRPV5 were observed in klotho-knockout mice, similar to the finding in FGF23-knockout mice, but klotho neither co-localizes with TRPV5 nor is regulated by FGF23. Rather, Andrukhova $\mathrm{O}$ et al. supported the notion that the apical membrane abundance of TRPV5 in renal distal tubules and renal calcium reabsorption are regulated by FGF23 through binding the FGFR-klotho complexes [59]. Based on these results, it can be propsed that FGF23 functions by binding to FGFR-klotho complexes, thus directly modulating calcium reabsorption in distal renal tubules. In contrast, hypocalcaemia (calcium deficiency) reduces the circulating concentrations of FGF23 [60]. This decrease in FGF23 might be a response that avoids a subsequent reduction in calcitriol, which could exacerbate hypocalcaemia. Additionally, Andrukhova $\mathrm{O}$ et al. found that FGF23 directly regulates sodium reabsorption in distal renal tubules by a signalling mechanism involving the FGFR-klotho complexes and the activation of ERK1/2, SGK1, and with-no-lysine kinase 4 (WNK4) signal cascades, suggesting that FGF23 is also a key regulator of renal sodium reabsorption and plasma volume [61]. This may explain the association of FGF23 with cardiovascular risk in CKD patients. Due to calcium and sodium disregulation in renal diseases [62], the novel link between FGF23 and the metabolism of these ions may have major pathophysiological implications in CKD [12].

Noticeably, membrane receptors of soluble klotho have not previously been identified. A recent study found that $\alpha 2-3$-sialyllactose, which is present in the glycan of monosialogangliosides, is a receptor of soluble klotho. Soluble klotho binds to ganglioside-enriched lipid rafts to regulate PI3K signalling [63]. Furthermore, another study identified the key protein residues in the Kl1 domain that are likely involved in binding to $\alpha 2-3$-sialyllactose, which down-regulates TRPC6 channels and protects against stress-induced cardiac hypertrophy [64]. These results provide new insight that targeting sialic acids may be a general mechanism underlying the pleiotropic actions of soluble klotho.

\section{Anti-inflammation}

Inflammation is multifactorial in CKD, and this disease is considered a prototypical example of inflammatory 
disease and premature ageing $[65,66]$. There are many proinflammatory factors increased gradually in CKD as renal function fails, including interleukin (IL)-6, serum fetuin-A, and tumour necrosis factor (TNF) [66, 67]. Nuclear factor $\kappa \mathrm{B}(\mathrm{NF}-\kappa \mathrm{B})$ controls many cellular processes, such as antiapoptotic responses, oxidative stress, and especially, inflammatory responses [68]. In normal situations, NF- $\mathrm{KB}$ is located in the cytoplasm in an inactive form, linked to its inhibitory proteins,termed inhibitory $\kappa B(\mathrm{I} \kappa \mathrm{B})$. In response to various stimuli, such as TNF, two serine residues at positions 32 and 36 in the $\mathrm{N}$-terminal region of IKB are phosphorylated. This phosphorylation induces ІкB ubiquitination by the E3-ІкB ubiquitin ligase complex, causing its degradation by the $26 \mathrm{~S}$ proteosome, thus leading to NF- $\mathrm{KB}$ translocation to the nucleus and the direct activation of downstream gene transcription $[23,68]$. Greater NF- $\kappa B$ activity increases the expression of proinflammatory mediators, such as cytokines and adhesion molecules. Several studies have shown that NF- $\mathrm{BB}$ plays a pivotal role in the progression of chronic renal inflammation, whereby the inhibition of NF- $\mathrm{KB}$ reduces the levels of several proinflammatory cytokines and renal injury [69-71].

One study has shown that there is a bidirectional relationship between klotho and NF-kB [23]. On the one hand, klotho expression is down-regulated by an NF- $\mathrm{kB}-$ dependent mechanism. Reduced klotho in the blood and urine has been observed in human CKD [72, 73]. In a nephrotoxic acute kidney injury (AKI) mouse model, klotho expression was also reduced, and blockage of TNF-related weak inducer of apoptosis (TWEAK), which is a member of the TNF superfamily, was able to revert kidney klotho levels and preserve renal function. Moreover, the inhibition of NF- $\kappa B$ prevents TWEAK-mediated decreases in klotho levels [74]. Thus, proinflammatory cytokines, such as TWEAK, negatively regulate the expression of klotho through an NF-kB-dependent mechanism, and NF- $\mathrm{KB}$ is a key contributor to the regulation of klotho expression [23].

On the other hand, klotho is an anti-inflammatory modulator that negatively regulated NF- $\mathrm{kB}$, consequently leading to a decrease in proinflammatory gene transduction. It has been reported that TNF increases vascular cell adhesion protein 1 (VCAM-1) and intercellular adhesion molecule 1 (ICAM-1) expressions in endothelial cells, while klotho can suppress TNF-induced increases in ICAM-1 and VCAM-1 expression by attenuating NF- $\mathrm{KB}$ activity [75]. Furthermore, in klotho-mutated mice, the exogenous addition of soluble klotho or the overexpression of membranous klotho in tissue culture suppresses NF- $\mathrm{KB}$ activation and NF- $\mathrm{kB}-$ mediated inflammatory cytokines via a mechanism that involves the phosphorylation of serine(536) in the transactivation domain of RelA [76]. Similarly, an excess of klotho inhibits the PDLIM2/NF-kB pathway to decrease the production of TNF- $\alpha$, IL-6, and IL-12, and to ameliorate cyclosporine A-induced nephropathy in vivo and in vitro [77]. In addition, klotho can suppress NADPH oxidase 2 (Nox2) protein expression and attenuate oxidative stress in rat aortic smooth muscle cells and can also suppress retinoic acid-inducible gene-I (RIG-I)-mediated inflammation [78, 79]. Thus, klotho may act as an anti-inflammatory modulator in the kidney.

\section{Protection against vascular calcification and mineral bone disorder}

Vascular calcification (VC) appears early in the course of CKD but becomes much more prevalent as kidney function deteriorates, creating a strong risk of cardiovascular mortality and morbidity in patients with CKD and ESRD [80, 81]. VC can be classified based on the vascular site of abnormal mineral deposition, including intimal calcification, medial calcification, and valvular calcification, which are all highly prevalent in the CKD population [82, 83]. It is now clear that VC is a cell-regulated pathological process that involves many inhibitors and inducers [5]. Under normal conditions, several inhibitors protect against VC by calcium and phosphate supersaturation, such as pyrophosphate, matrix Gla protein, and fetuin-A [84-88]. In the CKD population, the total function between inhibitors and inducers is unbalance, leading to the occurrence of $\mathrm{VC}$ in the vessel walls and valves. There are many inducers of $\mathrm{VC}$ in $\mathrm{CKD}$, including hypercalcaemia, inflammatory cytokines, and especially, phosphate $[88,89]$. Clinical evidence showed that the upregulation of serum phosphate is one of many risk factors for $\mathrm{VC}$ in the CKD population [90, 91]. Moreover, a growing amount of experimental research has revealed the mechanism of phosphate-induced VC, showing that PiT-1 which is phosphate cotransporter in vascular smooth muscle cells (SMCs), is involved in pathogenesis and promotes VC by induction of SMCs osteochondrogenic transformation and apoptosis and by regulation of extracellular vesicles release and stability [88, 92-94]. These results suggest that elevated phosphate is a main inducer of $\mathrm{VC}$.

The expression level of klotho decreases in patients with CKD and animal models, and is accompanied by renal disorders $[7,15]$. It has been reported that klotho deficiency causes high circulating levels of Phosphate and VC occurrence in mice with CKD. Conversely, overexpression of klotho can enhance phosphaturia, improve renal function, and produce much less calcification in vivo as well as suppress the sodium-dependent uptake of Phosphate and Phosphate-induced calcification of rat vascular SMCs [7]. Zhang et al. reported that cleaved klotho protein attenuates the Phosphate-induced human bone marrow mesenchymal stem cells differentiation into osteoblast-like cells in vitro via inactivation of the 
FGFR1/ERK signalling pathway [95]. In addition, the up-regulation of klotho expression by the inhibition of rapamycin signalling also ameliorates $\mathrm{VC}$ and protects against vascular disease in CKD [96, 97]. Another study showed that Intermedin 1-53 attenuates $\mathrm{VC}$ in rats with CKD by up-regulating membrane-bound klotho expression in the vessel wall [98]. Recent studies have confirmed that the stable delivery of soluble klotho can reduce chronic hyperphosphataemia and $\mathrm{VC}$ in vitro and in vivo [99], and activating peroxisome proliferator-activated receptor $\gamma$ enhanced the expression of klotho to inhibit Phosphate-induced VC in vascular SMCs [100]. These results suggested that klotho deficiency is closely associated with hyperphosphataemia and $\mathrm{VC}$ and that enhancing klotho activity plays a protective role in hyperphosphataemia and VC in CKD.

CKD-mineral bone disorder (MBD) is a newly termed systemic disorder that begins early in stage 2 of CKD and is characterized by abnormal serum biochemistries including hyperphosphataemia and hypercalacemia, bone disorders, and VC [88, 101]. The causes of VC and cardiovascular mortality associated with CKD are partly attributed to CKD-MBD [51, 102, 103]. Recent studies demonstrate that factors that are involved in renal injury and repair and that are released into the circulation contribute to the pathogenesis of CKD-MBD [51]; such factors include the Wnt signal inhibitors, Dickkopf 1 [104, 105] and sclerostin [106, 107], as well as activin A and ActRIIA [108, 109]. The pathogenic mechanisms of the components of CKD-MBD include VC, loss of renal klotho, hyperphosphataemia, osteodystrophy, vitamin D deficiency, increased FGF23, cardiovascular disease, and hyperparathyroidism [51]. In this review, we mainly focus on the aspects related to klotho. As described previously, the expression of klotho is significantly decreased in CKD. It has been reported that this decrease in klotho is partly related to activin and ActRIIA signalling. Furthermore, the activation of ActRIIA signalling by using a ligand trap for the receptor significantly stimulates klotho levels [108]. The resulting reduction in klotho limits its regulation of FGF23 production and leaves hyperphosphataemia as the principal regulator of FGF23 secretion in CKD [51]. Recently, researchers have identified that klotho loss is a key event in the renal and bone injuries in CKD-MBD mice, and endogenous klotho restoration by histone deacetylase inhibition attenuates CKD-associated bone complications in a mouse model of CKD-MBD [110]. Similarly, rhein-regulated klotho expression by promoter hypermethylation protects against renal and bone injuries in mice with CKD. When klotho is knocked down by RNA interference, the renal protective effects of rhein are largely abolished [111]. These data suggest that klotho deficiency is closely associated with the development of CKD-MBD and that klotho restoration is beneficial to the improvement of VC and CKD-MBD.

\section{Amelioration of renal fibrosis}

The final common pathological manifestation of many instances of CKD is renal fibrosis. Renal fibrosis represents the unsuccessful wound healing of kidney tissue after chronic, sustained injury and is characterized by glomerulosclerosis, tubular atrophy, and interstitial fibrosis [112]. The progression of CKD is evidenced by a loss of renal cells and their replacement by extracellular matrix (ECM) in the glomeruli and interstitium $[66,113]$. The pathogeneses of glomerulosclerosis and tubulointerstitial fibrosis are extremely similar [113]. In essence, renal injury results in an inflammatory cascade involving macrophage activation and T-cells recruitment, triggering an immune response and causing interstitial nephritis. Then, several cell types including macrophages, T-cells, and tubular epithelial cells respond to this inflammatory process to produce profibrotic mediators, such as transforming growth factor $\beta$ (TGF- $\beta$ ). Under the influence of profibrotic cytokines, injured tubular epithelial cells dedifferentiate and lose their polarity and transporter function, reorganize their cytoskeleton into stress fibres, disrupt the tubular basement membrane, and migrate into the interstitium, where they synthesize increasing amounts of ECM, finally leading to renal fibrosis [114-116].

Many studies indicate that TGF- $\beta$ is one of the most important profibrotic regulators of renal fibrosis in progressive CKD and stimulates the accumulation of matrix proteins to induce ECM, inhibits matrix degradation, and regulates myofibroblast activation [117-120]. Based on the role of TGF- $\beta$, many therapeutic approaches involving the inhibition of TGF- $\beta$ have been tested in experimental models of CKD and clinical trials, such as the administration of neutralizing anti-TGF- $\beta$ antibodies and small interfering RNAs that target the TGF- $\beta$ type II receptor, which can reduce structural renal injury and decrease renal fibrosis in CKD [121-123]. It has been reported that klotho inhibition increases TGF- $\beta 1$ expression in mice with renal fibrosis that has been induced by unilateral ureteral obstruction (UUO), and TGF- $\beta 1$ reduces klotho expression in renal cultured epithelial cells, suggesting that decreased klotho expression enhances TGF- $\beta 1$ activity and that klotho deficiency is not only a cause but also a result of renal fibrosis in CKD [124]. In contrast, soluble klotho protein directly binds to the TGF- $\beta$ type-II receptor and inhibits TGF- $\beta 1$ binding to cell surface receptors, thereby inhibiting TGF- $\beta 1$ signalling in mice with UUO-induced renal fibrosis. Moreover, klotho decreases epithelial marker expression and increases mesenchymal marker expression to suppress the TGF- $\beta 1$-induced epithelial-tomesenchymal transition in renal epithelial cells [125]. These results indicate that klotho can suppress renal fibrosis by inhibiting TGF- $\beta 1$ activity.

Another principal profibrotic molecule is named angiotensin II (Ang II); this molecule modulates fibrosis 
by direct effects on the matrix and by up-regulating the expression of other factors, such as TGF- $\beta$ [126, 127], connective tissue growth factor [128], plasminogen activator inhibitor-1 [129], tumour necrosis factor- $\alpha$, and NF- $\mathrm{kB}$ $[113,130]$. Furthermore, data have shown that Ang II-induced renal damage suppresses klotho expression, whereas the induction of klotho gene expression mitigates Ang II-induced renal damage [131]. In addition, soluble klotho has been shown to inhibit Wnt and IGF-1 signalling, which can promote the epithelial-to-mesenchymal transition and myofibroblast activation [125, 132]. Recent studies also show that exogenous klotho decreases high glucose-induced fibronectin and cell hypertrophy via the ERK1/2-p38 kinase signalling pathway to attenuate diabetic nephropathy in vitro [133] and that the administration of klotho protein suppresses renal tubulo-interstitial fibrosis and UUO-induced renal fibrosis, at least partly, by controlling basic fibroblast growth factor- 2 signalling in vivo [134]. These results raise the possibility that soluble klotho may function as a renal-protective factor against fibrosis by inhibiting multiple signalling pathways.

\section{Potential use of klotho in human chronic kidney disease A potential biomarker for CKD}

CKD is not easy to detected at early stage of CKD and thus it is very difficult to make an early and accurate diagnosis. And there are no biomarkers which are able to be measured easily, sensitively, reliably, and specially, in correlation with presence, development, and complications of CKD [135]. As described previously, renal klotho deficiency is highly associated with ion disorders, $\mathrm{VC}$, inflammation, renal fibrosis, and mineral bone disorder, which are all characteristics of CKD. It has been shown that soluble klotho in the circulation starts to decline early in stage 2 CKD and urinary klotho possibly declines even earlier 1 [14]. In addition, data show that klotho deficiency in CKD can enhance the renal tubular and vascular cell senescence induced by oxidative stress $[136,137]$ and can result in defective endothelial function and impaired vasculogenesis [138]. Together, these findings indicate that klotho deficiency is closely correlated with the development and progression of CKD and extrarenal complications. Thus, soluble klotho deficiency seems to have diagnostic potential, serving as an early and sensitive biomarker of CKD.

Many researchers have investigated the possibility of using klotho as a biomarker for CKD. CKD-MBD is one of the striking features associated with the high morbidity and mortality of cardiovascular events in CKD and ESRD [51, 139]. Abnormal mineral metabolism includes high serum phosphate, FGF23, and PTH levels, which are closely associated with or even induced by klotho deficiency [14, 140-142]. Clinical studies in patients with CKD have shown that soluble klotho is lower than normal $(519 \pm 183$ versus $845 \pm 330 \mathrm{pg} / \mathrm{mL}, P<.0001)$ in renal patients, and soluble klotho is positively correlated with serum calcium and negatively correlated with serum phosphate, PTH, and FGF23, suggesting that soluble klotho might reflect the ensuing tubular resistance to FGF23, which could be an early marker of CKD-MBD [143, 144]. Recently, another clinical study suggested that soluble klotho is significantly associated with phosphate reabsorption independently of FGF-23, which may be a marker of phosphate reabsorption [145]. Therefore, soluble klotho seems to be a marker for disorders of phosphate and bone metabolism in CKD.

GFR, the gold standard for assessing kidney function, is significantly decreased in CKD [112]. Clinical and experimental studies have shown that this significant decrease in klotho in the kidneys is positively associated with estimated GFR (eGFR) in CKD samples [144-147]. Several other studies have confirmed the positive correlation between klotho levels (in serum and urine) and eGFR in adult patients with CKD [7,33]. Moreover, both serum and urine klotho levels are independently associated with eGFR in patients with CKD [33, 148]. Another study showed that serum klotho levels are progressively lower with advancing CKD stage, with an adjusted mean decrease of $3.2 \mathrm{pg} / \mathrm{mL}$ for each $1 \mathrm{~mL} / \mathrm{min} / 1.73 \mathrm{~m}^{2}$ eGFR decrease [149]. Consistently, a similar positive correlation between plasma klotho levels and eGFR was shown in children with CKD [150]. These results suggest that the decrease in soluble klotho may mirror an eGFR decrease in patients with CKD.

However, some researchers obtained adverse results. Sarah Seiler et al. analysed a large cohort of 312 patients with stage 2-4 CKD and found that plasma klotho levels were not significantly associated with eGFR or other calcium-phosphate metabolism parameters in these patients [151]. Similarly, in a prospective observational study among 444 patients with CKD stages 2-4, klotho levels were not significantly related to cardiovascular outcomes [152]. These results indicate that plasma klotho levels are not related to kidney function and do not predict adverse outcome in patients with CKD. There may be two reasons for this contradictory data. One is age. Yamazaki et al. suggested that soluble klotho levels are correlated with age, finding that klotho levels are higher in children (mean age 7.1 \pm 4.8 years) than in adults [153]. Shimamura et al. also reported significantly lower klotho levels in CKD stage 2-5 patients than in CKD stage 1 patients. Moreover, this finding was largely based on data from four young individuals with normal eGFR and extremely high klotho levels, whereas klotho levels in the remaining participants did not predict adverse outcome of CKD [143, 151]. Furthermore, a recent clinical study found that an allele of the G-395A klotho gene polymorphism has a significantly higher frequency 
among children with CKD, suggesting that this mutant allele of klotho can be used as a risk marker for the development of ESRD and as a predictor of CVD in children [154]. Another reason may be the differences in sample size. The results obtained from some studies with small cohorts of CKD patients [155-157] were different from those obtained with a large cohort [151]. The idea of a decline in klotho levels with impaired kidney function has been further disputed by smaller studies $[151,155,158]$.

Although the results of relations between circulating klotho levels and outcomes of CKD are contradictory, three commonly used commercial immunoassay products for measuring soluble klotho-- are available from IBL (IBL International GmbH, Hamburg, Germany), Cusabio (Cusabio Biotech, Wuhan, China), and USCN (USCN Life Science Inc., Wuhan, China) [159]. Only the IBL kit provides information on epitope specificity [159]. However, researchers have found that these assays exhibited poor performance, including a lack of unit standardization in readouts, and the assays have to be improved to produce accurate results before they can provide reliable conclusions [160].

\section{As a potential treatment strategy for CKD}

Although the causes of CKD are multifactorial, klotho deficiency is significantly associated with the development and progression of CKD and extrarenal complications. Many clinical and animal studies have suggested that when the klotho-deficient state in CKD is rescued, the renal function, morphologic lesion, and complications of CKD are obviously improved $[4,14,16,135,148,161]$. For example, the administration of soluble klotho protein significantly attenuated UUO-induced renal fibrosis and suppressed the expression of fibrosis markers and TGF- $\beta 1$ target genes, such as Snail and Twist [125]. Furthermore, klotho connected intermedin 1-53 to the suppression of VC in CKD rats [162], and klotho supplementation suppressed the renin-angiotensin system to ameliorate Adriamycin nephropathy. In addition, klotho protein appeared to suppress the epithelial-mesenchymal transition by inhibiting
TGF- $\beta$ and Wnt signalling [163]. Therefore, klotho deficiency may not only be a pathogenic intermediate in the acceleration of CKD progression but may also be a major contributor to chronic complications, such as CKD-MBD and cardiovascular diseases in CKD. Conceivably, any therapy that restores the klotho level by supplementation with exogenous klotho and/or the up-regulation of endogenous klotho production might be a novel treatment strategy for CKD [14].

Several methods are dependent on various mechanisms to increase klotho expression (Table 1) [14]; these includethe following: (1) Demethylation. Methylation of the klotho gene promoter reduces its activity by $30 \%$ to $40 \%$, whereas DNA demethylation increases klotho expression 1.5-fold to threefold [164]. (2) Deacetylation. Data show that the TNF and TWEAK-induced down-regulation of klotho expression in the kidney and kidney cell lines can be blunted by the inhibition of histone deacetylase [74]. (3) Drugs. Several drugs on the market have been shown to up-regulate klotho expression in vivo and/or in vitro, including PPAR- $\gamma$ agonists [165], angiotensin II-type I receptor antagonists [166], vitamin $\mathrm{D}$ active derivatives [167, 168], and intermedin [98]. (4) Klotho gene delivery. Klotho gene delivery through a viral carrier has been shown to effectively improve multiple pathophysiological phenotypes in klotho-deficient mice [169], thereby preventing the progression of kidney damage in rat models [170] and improving VC and endothelial function in CKD [80]. (5) Administration of soluble klotho protein. Increasing circulating klotho levels through the administration of soluble klotho protein, which is the cleaved, full-length extracellular domain of membrane klotho, is more direct, safer, and an easier modality to restore endocrine klotho deficiency [14, 72]. Animal studies have shown that the bolus administration of soluble klotho protein is a safe and effective means for protecting against kidney injury and preserving renal function $[14,72]$.

\section{Conclusions}

As the FGF23 co-receptor, klotho mediates FGF23 to regulate mineral ion (such as calcium and phosphate)

Table 1 Potential treatment strategies for CKD via the up-regulation of klotho

\begin{tabular}{|c|c|}
\hline Methods & Mechanism \\
\hline DNA demethylation & Methylation of the klotho gene promoter reduces its activity by $30-40 \%$ \\
\hline Histone deacetylation & $\begin{array}{l}\text { Hyperacetylation of histone in the klotho promoter down-regulates klotho } \\
\text { expression }\end{array}$ \\
\hline $\begin{array}{l}\text { Drugs: PPAR- } y \text { agonists, angiotensin II-type I receptor antagonists, } \\
\text { statin, vitamin D active derivatives, intermedin }\end{array}$ & These drugs can up-regulate klotho expression in vitro and in vivo \\
\hline Delivery of klotho cDNA & $\begin{array}{l}\text { The klotho gene is transfected by viral carrier into target cells or animal } \\
\text { models }\end{array}$ \\
\hline Soluble klotho protein administration & $\begin{array}{l}\text { Recombinant klotho protein, which is the cleaved, full-length extracellular } \\
\text { domain of membrane klotho, can be injected }\end{array}$ \\
\hline
\end{tabular}


homeostasis via klotho-FGFR complexes. Moreover, a recent study acknowledged that klotho is an on-demand non-enzymatic molecular scaffold protein that promotes FGF23 signalling. The identification of lipid rafts and sialogangliosides as the membrane receptors of soluble klotho helps us to understand more about how klotho functions as a circulating hormone or local autocrine/ paracrine factor. However, klotho functions exert pleiotropic actions in the circulation. Thus, the klotho crystal structure, secretion, and regulation mechanism should be clarified in detail. A further understanding of the relation between klotho levels and CKD as well as its potential applications in vivo is very important for future therapeutic application.

\begin{abstract}
Abbreviations
1,25(OH)2D: 1a,25-dihydroxyvitamin D3; AKl: Acute kidney injury; Ang II: Angiotensin II; CKD: Chronic kidney disease; ECM: Extracellular matrix; ERK: Extracellular signal-regulated kinase; ESRD: End-stage renal disease; FGF: Fibroblast growth factor; FGFR: FGF receptors; GFR: Glomerular filtration rate; ICAM-1: Intercellular adhesion molecule 1; IL: Interleukin; IKB: Inhibitory KB; MBD: Mineral bone disorder; NF-KB: Nuclear factor KB; NHERF: Na+/H+ exchange regulatory cofactor; Nox2: NAPDH oxidase 2; PTH: Parathyroid hormone; RIG-I: Acid-inducible gene-l; SGK: Serum/glucocorticoid-regulated kinase; SMCs: Smooth muscle cells; TGF- $\beta$ : Transforming growth factor $\beta$; TNF: Tumour necrosis factor; TRPV5: Transient receptor potential vannilloid-5; TWEAK: TNF-related weak inducer of apoptosis; UUO: Unilateral ureteral obstruction; VC: Vascular calcification; VCAM-1: Vascular cell adhesion protein 1; WNK4: With-no-lysine kinase 4
\end{abstract}

\section{Acknowledgements}

Not applicable.

\section{Funding}

There was no funding

\section{Availability of data and materials}

Not applicable.

\section{Authors' contributions}

JG was responsible for the overall organization, structure, and ideas expressed in the paper. DZ was responsible for drafting the paper. $\mathrm{YH}$ and SM provided the reference materials, and edited and modified the paper. WW designed the figure and table in the manuscript, and helped to answer the reviewer's questions and edit the language. All authors read and approved the final manuscript.

\section{Ethics approval and consent to participate}

Not applicable.

\section{Consent for publication}

Not applicable.

\section{Competing interests}

The authors declare that they have no competing interests.

\section{Publisher's Note}

Springer Nature remains neutral with regard to jurisdictional claims in published maps and institutional affiliations.

\section{Author details}

'Department of Nephrology, The First Affiliated Hospital to Changchun University of Chinese Medicine, Changchun, Jilin 130000, China. ${ }^{2}$ Department of Medical Ultrasonics, PLA Army General Hospital, Beijing 100700, China. ${ }^{3}$ Department of Urology, China-Japan Union Hospital, Jilin University, Changchun, Jilin 130000, China.
Received: 31 July 2017 Accepted: 9 October 2018

Published online: 22 October 2018

\section{References}

1. Hu MC, Shi M, Gillings N, Flores B, Takahashi M, Kuro OM, Moe OW. Recombinant alpha-Klotho may be prophylactic and therapeutic for acute to chronic kidney disease progression and uremic cardiomyopathy. Kidney Int. 2017;91(5):1104-14.

2. Zoja C, Abbate M, Remuzzi G. Progression of chronic kidney disease: insights from animal models. Curr Opin Nephrol Hypertens. 2006;15(3):250-7.

3. Cortinovis M, Ruggenenti $P$, Remuzzi G. Progression, Remission and Regression of Chronic Renal Diseases. Nephron. 2016;134(1):20-4.

4. Hu MC, Kuro-o M, Moe OW. Klotho and chronic kidney disease. Contrib Nephrol. 2013;180:47-63.

5. Giachelli CM. The emerging role of phosphate in vascular calcification. Kidney Int. 2009;75(9):890-7.

6. Lindberg K, Amin R, Moe OW, Hu MC, Erben RG, Ostman Wernerson A, Lanske B, Olauson H, Larsson TE. The kidney is the principal organ mediating klotho effects. J Am Soc Nephrol. 2014;25(10):2169-75.

7. Hu MC, Shi M, Zhang J, Quinones H, Griffith C, Kuro-o M, Moe OW. Klotho deficiency causes vascular calcification in chronic kidney disease. J Am Soc Nephrol. 2011;22(1):124-36.

8. Komaba H, Kaludjerovic J, Hu DZ, Nagano K, Amano K, Ide N, Sato T, Densmore MJ, Hanai Jl, Olauson H, et al. Klotho expression in osteocytes regulates bone metabolism and controls bone formation. Kidney Int. 2017

9. Kato Y, Arakawa E, Kinoshita S, Shirai A, Furuya A, Yamano K, Nakamura K, lida A, Anazawa H, Koh N, et al. Establishment of the anti-Klotho monoclonal antibodies and detection of Klotho protein in kidneys. Biochem Biophys Res Commun. 2000;267(2):597-602.

10. Kuro-o M, Matsumura Y, Aizawa H, Kawaguchi H, Suga T, Utsugi T, Ohyama Y, Kurabayashi M, Kaname T, Kume E, et al. Mutation of the mouse klotho gene leads to a syndrome resembling ageing. Nature. 1997;390(6655):45-51.

11. Hu MC, Shi M, Zhang J, Pastor J, Nakatani T, Lanske B, Razzaque MS, Rosenblatt KP, Baum MG, Kuro-o M, et al. Klotho: a novel phosphaturic substance acting as an autocrine enzyme in the renal proximal tubule. FASEB J. 2010;24(9):3438-50.

12. Erben RG, Andrukhova O. FGF23-Klotho signaling axis in the kidney. Bone. 2017;100:26-28.

13. Hu MC, Shi M, Zhang J, Addo T, Cho HJ, Barker SL, Ravikumar P, Gillings N, Bian A, Sidhu SS, et al. Renal Production, Uptake, and Handling of Circulating alphaKlotho. J Am Soc Nephrol. 2016:27(1):79-90.

14. Neyra JA, Hu MC. Potential application of klotho in human chronic kidney disease. Bone. 2017;100:41-49.

15. Lau WL, Leaf EM, Hu MC, Takeno MM, Kuro-o M, Moe OW, Giachelli CM. Vitamin D receptor agonists increase klotho and osteopontin while decreasing aortic calcification in mice with chronic kidney disease fed a high phosphate diet. Kidney Int. 2012;82(12):1261-70.

16. Hu MC, Kuro-o M, Moe OW. Renal and extrarenal actions of Klotho. Semin Nephrol. 2013;33(2):118-29.

17. Eckardt KU, Coresh J, Devuyst O, Johnson RJ, Kottgen A, Levey AS, Levin A Evolving importance of kidney disease: from subspecialty to global health burden. Lancet. 2013;382(9887):158-69.

18. Hu MC, Shiizaki K, Kuro-o M, Moe OW. Fibroblast growth factor 23 and Klotho: physiology and pathophysiology of an endocrine network of mineral metabolism. Annu Rev Physiol. 2013;75:503-33.

19. Kuro OM, Moe OW. FGF23-alphaKlotho as a paradigm for a kidney-bone network. Bone. 2017;100:4-18.

20. Ito S, Fujimori T, Hayashizaki $Y$, Nabeshima Y. Identification of a novel mouse membrane-bound family 1 glycosidase-like protein, which carries an atypical active site structure. Biochim Biophys Acta. 2002;1576(3):341-5.

21. Ito S, Kinoshita S, Shiraishi N, Nakagawa S, Sekine S, Fujimori T, Nabeshima YI. Molecular cloning and expression analyses of mouse betaklotho, which encodes a novel Klotho family protein. Mech Dev. 2000;98(1-2):115-9.

22. Yahata K, Mori K, Arai H, Koide S, Ogawa Y, Mukoyama M, Sugawara A, Ozaki S, Tanaka I, Nabeshima Y, et al. Molecular cloning and expression of a novel klotho-related protein. J Mol Med (Berl). 2000;78(7):389-94.

23. Buendia P, Ramirez R, Aljama P, Carracedo J. Klotho Prevents Translocation of NFkappaB. Vitam Horm. 2016;101:119-50.

24. Matsumura Y, Aizawa H, Shiraki-lida T, Nagai R, Kuro-o M, Nabeshima Y. Identification of the human klotho gene and its two transcripts encoding 
membrane and secreted klotho protein. Biochem Biophys Res Commun. 1998;242(3):626-30.

25. Bloch L, Sineshchekova O, Reichenbach D, Reiss K, Saftig P, Kuro-o M, Kaether $C$. Klotho is a substrate for alpha-, beta- and gamma-secretase. FEBS Lett. 2009;583(19):3221-4.

26. Chen CD, Podvin S, Gillespie E, Leeman SE, Abraham CR. Insulin stimulates the cleavage and release of the extracellular domain of Klotho by ADAM10 and ADAM17. Proc Natl Acad Sci U S A. 2007;104(50):19796-801.

27. Chen CD, Tung TY, Liang J, Zeldich E, Tucker Zhou TB, Turk BE, Abraham CR Identification of cleavage sites leading to the shed form of the anti-aging protein klotho. Biochemistry. 2014;53(34):5579-87.

28. Shiraki-lida T, Aizawa H, Matsumura Y, Sekine S, lida A, Anazawa H, Nagai R, Kuroo M, Nabeshima Y. Structure of the mouse klotho gene and its two transcripts encoding membrane and secreted protein. FEBS Lett. 1998;424(1-2):6-10.

29. Mencke R, Olauson H, Hillebrands JL. Effects of Klotho on fibrosis and cancer: A renal focus on mechanisms and therapeutic strategies. Adv Drug Deliv Rev. 2017;121:85-100.

30. Mencke R, Harms G, Moser J, van Meurs M, Diepstra A, Leuvenink HG, Hillebrands JL. Human alternative Klotho mRNA is a nonsense-mediated mRNA decay target inefficiently spliced in renal disease. JCI Insight. 2017;2(20):1-15.

31. Kurosu H, Yamamoto M, Clark JD, Pastor JV, Nandi A, Gurnani P, McGuinness OP, Chikuda H, Yamaguchi M, Kawaguchi $H$, et al. Suppression of aging in mice by the hormone Klotho. Science. 2005;309(5742):1829-33.

32. Imura A, Iwano A, Tohyama O, Tsuji Y, Nozaki K, Hashimoto N, Fujimori T, Nabeshima Y. Secreted Klotho protein in sera and CSF: implication for posttranslational cleavage in release of Klotho protein from cell membrane. FEBS Lett. 2004;565(1-3):143-7.

33. Akimoto $T$, Yoshizawa H, Watanabe $Y$, Numata A, Yamazaki T, Takeshima E, Iwazu K, Komada T, Otani N, Morishita Y, et al. Characteristics of urinary and serum soluble Klotho protein in patients with different degrees of chronic kidney disease. BMC Nephrol. 2012;13:155.

34. Semba RD, Moghekar AR, Hu J, Sun K, Turner R, Ferrucci L, O'Brien R. Klotho in the cerebrospinal fluid of adults with and without Alzheimer's disease. Neurosci Lett. 2014;558:37-40.

35. Shimada T, Mizutani S, Muto T, Yoneya T, Hino R, Takeda S, Takeuchi Y, Fujita T, Fukumoto S, Yamashita T. Cloning and characterization of FGF23 as a causative factor of tumor-induced osteomalacia. Proc Natl Acad Sci U S A. 2001;98(11):6500-5.

36. Shimada T, Hasegawa H, Yamazaki Y, Muto T, Hino R, Takeuchi Y, Fujita T, Nakahara K, Fukumoto S, Yamashita T. FGF-23 is a potent regulator of vitamin D metabolism and phosphate homeostasis. J Bone Miner Res. 2004;19(3):429-35.

37. Martin A, David V, Quarles LD. Regulation and function of the FGF23/klotho endocrine pathways. Physiol Rev. 2012;92(1):131-55.

38. Ornitz DM, Itoh N. The Fibroblast Growth Factor signaling pathway. Wiley Interdiscip Rev Dev Biol. 2015;4(3):215-66

39. Urakawa I, Yamazaki Y, Shimada T, lijima K, Hasegawa H, Okawa K, Fujita T, Fukumoto S, Yamashita T. Klotho converts canonical FGF receptor into a specific receptor for FGF23. Nature. 2006;444(7120):770-4

40. Kurosu H, Ogawa Y, Miyoshi M, Yamamoto M, Nandi A, Rosenblatt KP, Baum MG, Schiavi S, Hu MC, Moe OW, et al. Regulation of fibroblast growth factor-23 signaling by klotho. J Biol Chem. 2006;281(10):6120-3.

41. Chen G, Liu Y, Goetz R, Fu L, Jayaraman S, Hu MC, Moe OW, Liang G, Li X, Mohammadi M. alpha-Klotho is a non-enzymatic molecular scaffold for FGF23 hormone signalling. Nature. 2018;553(7689):461-6.

42. Deliot N, Hernando N, Horst-Liu Z, Gisler SM, Capuano P, Wagner CA, Bacic D, O'Brien S, Biber J, Murer H. Parathyroid hormone treatment induces dissociation of type lla $\mathrm{Na}+-\mathrm{P}(\mathrm{i})$ cotransporter- $\mathrm{Na}+/ \mathrm{H}+$ exchanger regulatory factor-1 complexes. Am J Physiol Cell Physiol. 2005;289(1):C159-67.

43. Larsson T, Marsell R, Schipani E, Ohlsson C, Ljunggren O, Tenenhouse HS, Juppner $\mathrm{H}$, Jonsson KB. Transgenic mice expressing fibroblast growth factor 23 under the control of the alpha1(I) collagen promoter exhibit growth retardation, osteomalacia, and disturbed phosphate homeostasis. Endocrinology. 2004;145(7):3087-94

44. Andrukhova O, Zeitz U, Goetz R, Mohammadi M, Lanske B, Erben RG. FGF23 acts directly on renal proximal tubules to induce phosphaturia through activation of the ERK1/2-SGK1 signaling pathway. Bone. 2012;51(3):621-8.

45. Ide N, Olauson H, Sato T, Densmore MJ, Wang H, Hanai J, Larsson TE, Lanske B. In vivo evidence for a limited role of proximal tubular Klotho in renal phosphate handling. Kidney Int. 2016;90(2):348-62.

46. Yoshida T, Fujimori T, Nabeshima Y. Mediation of unusually high concentrations of 1,25-dihydroxyvitamin D in homozygous klotho mutant mice by increased expression of renal 1alpha-hydroxylase gene. Endocrinology. 2002;143(2):683-9.

47. Shimada T, Kakitani M, Yamazaki Y, Hasegawa H, Takeuchi Y, Fujita T, Fukumoto S, Tomizuka K, Yamashita T. Targeted ablation of Fgf23 demonstrates an essential physiological role of FGF23 in phosphate and vitamin D metabolism. J Clin Invest. 2004;113(4):561-8.

48. Murali SK, Roschger P, Zeitz U, Klaushofer K, Andrukhova O, Erben RG. FGF23 Regulates Bone Mineralization in a 1,25(OH)2 D3 and KlothoIndependent Manner. J Bone Miner Res. 2016;31(1):129-42.

49. Sakan H, Nakatani K, Asai O, Imura A, Tanaka T, Yoshimoto S, Iwamoto N, Kurumatani N, Iwano M, Nabeshima Y, et al. Reduced renal alpha-Klotho expression in CKD patients and its effect on renal phosphate handling and vitamin D metabolism. PloS one. 2014;9(1):e86301.

50. Smith RC, O'Bryan LM, Farrow EG, Summers LJ, Clinkenbeard EL, Roberts $J$, Cass TA, Saha J, Broderick C, Ma YL, et al. Circulating alphaKlotho influences phosphate handling by controlling FGF23 production. J Clin Invest. 2012; 122(12):4710-5.

51. Hruska KA, Sugatani T, Agapova O, Fang Y. The chronic kidney disease Mineral bone disorder (CKD-MBD): Advances in pathophysiology. Bone. 2017;100:80-6.

52. Gattineni J, Bates C, Twombley K, Dwarakanath V, Robinson ML, Goetz R Mohammadi M, Baum M. FGF23 decreases renal NaPi-2a and NaPi-2C expression and induces hypophosphatemia in vivo predominantly via FGF receptor 1. Am J Physiol Renal Physiol. 2009;297(2):F282-91.

53. Han X, Yang J, Li L, Huang J, King G, Quarles LD. Conditional Deletion of Fgfr1 in the Proximal and Distal Tubule Identifies Distinct Roles in Phosphate and Calcium Transport. PloS one. 2016;11(2):e0147845.

54. Isakova T, Wahl P, Vargas GS, Gutierrez OM, Scialla J, Xie H, Appleby D, Nessel L, Bellovich K, Chen J, et al. Fibroblast growth factor 23 is elevated before parathyroid hormone and phosphate in chronic kidney disease. Kidney Int. 2011;79(12):1370-8.

55. Barker SL, Pastor J, Carranza D, Quinones H, Griffith C, Goetz R, Mohammadi M, Ye J, Zhang J, Hu MC, et al. The demonstration of alphaKlotho deficiency in human chronic kidney disease with a novel synthetic antibody. Nephrol Dial Transplant. 2015;30(2):223-33.

56. Dhayat NA, Ackermann D, Pruijm M, Ponte B, Ehret G, Guessous I, Leichtle $A B$, Paccaud F, Mohaupt M, Fiedler GM, et al. Fibroblast growth factor 23 and markers of mineral metabolism in individuals with preserved renal function. Kidney Int. 2016;90(3):648-57.

57. Chang Q, Hoefs S, van der Kemp AW, Topala CN, Bindels RJ, Hoenderop JG. The beta-glucuronidase klotho hydrolyzes and activates the TRPV5 channel. Science. 2005;310(5747):490-3.

58. Cha SK, Ortega B, Kurosu H, Rosenblatt KP, Kuro OM, Huang CL. Removal of sialic acid involving Klotho causes cell-surface retention of TRPV5 channel via binding to galectin-1. Proc Natl Acad Sci U S A. 2008;105(28):9805-10.

59. Andrukhova O, Smorodchenko A, Egerbacher M, Streicher C, Zeitz U, Goetz R, Shalhoub V, Mohammadi M, Pohl EE, Lanske B, et al. FGF23 promotes renal calcium reabsorption through the TRPV5 channel. EMBO J. 2014;33(3):229-46.

60. Rodriguez-Ortiz ME, Lopez I, Munoz-Castaneda JR, Martinez-Moreno JM, Ramirez AP, Pineda C, Canalejo A, Jaeger P, Aguilera-Tejero E, Rodriguez M, et al. Calcium deficiency reduces circulating levels of FGF23. J Am Soc Nephrol. 2012;23(7):1190-7.

61. Andrukhova O, Slavic S, Smorodchenko A, Zeitz U, Shalhoub V, Lanske B, Pohl EE, Erben RG. FGF23 regulates renal sodium handling and blood pressure. EMBO Mol Med. 2014;6(6):744-59.

62. Langston C. Managing Fluid and Electrolyte Disorders in Kidney Disease. Vet Clin North Am Small Anim Pract. 2017;47(2):471-90.

63. Dalton G, An SW, Al-Juboori SI, Nischan N, Yoon J, Dobrinskikh E, Hilgemann DW, Xie J, Luby-Phelps K, Kohler JJ, et al. Soluble klotho binds monosialoganglioside to regulate membrane microdomains and growth factor signaling. Proc Natl Acad Sci U S A. 2017;114(4):752-7.

64. Wright JD, An SW, Xie J, Yoon J, Nischan N, Kohler JJ, Oliver N, Lim C, Huang CL. Modeled structural basis for the recognition of alpha2-3sialyllactose by soluble Klotho. FASEB J. 2017;31(8):3574-86.

65. Stenvinkel P, Larsson TE. Chronic kidney disease: a clinical model of premature aging. Am J Kidney Dis. 2013;62(2):339-51.

66. Zoccali C, Vanholder R, Massy ZA, Ortiz A, Sarafidis P, Dekker FW, Fliser D, Fouque $\mathrm{D}$, Heine $\mathrm{GH}$, Jager KJ, et al. The systemic nature of CKD. Nat Rev Nephrol. 2017;13(6):344-58.

67. Mehrotra R, Westenfeld R, Christenson P, Budoff M, Ipp E, Takasu J, Gupta A, Norris K, Ketteler M, Adler S. Serum fetuin-A in nondialyzed patients with 
diabetic nephropathy: relationship with coronary artery calcification. Kidney Int. 2005;67(3):1070-7.

68. Ghosh S. Dass JF: Study of pathway cross-talk interactions with NF-kappaB leading to its activation via ubiquitination or phosphorylation: A brief review. Gene. 2016;584(1):97-109.

69. Volpini RA, Costa RS, da Silva CG, Coimbra TM. Inhibition of nuclear factorkappaB activation attenuates tubulointerstitial nephritis induced by gentamicin. Nephron Physiol. 2004;98(4):p97-106.

70. Fujihara CK, Antunes GR, Mattar AL, Malheiros DM, Vieira JM Jr, Zatz R. Chronic inhibition of nuclear factor-kappaB attenuates renal injury in the 5/ 6 renal ablation model. Am J Physiol Renal Physiol. 2007;292(1):F92-9.

71. Ding W, Yang L, Zhang M, Gu Y. Chronic inhibition of nuclear factor kappa B attenuates aldosterone/salt-induced renal injury. Life Sci. 2012;90(15-16):600-6.

72. Hu MC, Shi M, Zhang J, Quinones H, Kuro-o M, Moe OW. Klotho deficiency is an early biomarker of renal ischemia-reperfusion injury and its replacement is protective. Kidney Int. 2010;78(12):1240-51.

73. Izquierdo MC, Perez-Gomez MV, Sanchez-Nino MD, Sanz AB, Ruiz-Andres O, Poveda J, Moreno JA, Egido J, Ortiz A. Klotho, phosphate and inflammation/ageing in chronic kidney disease. Nephrol Dial Transplant. 2012;27(Suppl 4):iv6-10.

74. Moreno JA, Izquierdo MC, Sanchez-Nino MD, Suarez-Alvarez B, Lopez-Larrea C, Jakubowski A, Blanco J, Ramirez R, Selgas R, Ruiz-Ortega M, et al. The inflammatory cytokines TWEAK and TNFalpha reduce renal klotho expression through NFkappaB. J Am Soc Nephrol. 2011;22(7):1315-25.

75. Maekawa Y, Ishikawa K, Yasuda O, Oguro R, Hanasaki H, Kida I, Takemura Y, Ohishi M, Katsuya T, Rakugi H. Klotho suppresses TNF-alpha-induced expression of adhesion molecules in the endothelium and attenuates NFkappaB activation. Endocrine. 2009;35(3):341-6.

76. Zhao Y, Banerjee S, Dey N, LeJeune WS, Sarkar PS, Brobey R, Rosenblatt KP, Tilton RG, Choudhary S. Klotho depletion contributes to increased inflammation in kidney of the $\mathrm{db} / \mathrm{db}$ mouse model of diabetes via RelA (serine)536 phosphorylation. Diabetes. 2011;60(7):1907-16.

77. Jin M, Lv P, Chen G, Wang P, Zuo Z, Ren L, Bi J, Yang CW, Mei X, Han D. Klotho ameliorates cyclosporine A-induced nephropathy via PDLIM2/NF-kB p65 signaling pathway. Biochem Biophys Res Commun. 2017:486(2):451-7.

78. Wang Y, Kuro-o M, Sun Z. Klotho gene delivery suppresses Nox2 expression and attenuates oxidative stress in rat aortic smooth muscle cells via the cAMP-PKA pathway. Aging Cell. 2012;11(3):410-7.

79. Liu F, Wu S, Ren H, Gu J. Klotho suppresses RIG-I-mediated senescenceassociated inflammation. Nat Cell Biol. 2011;13(3):254-62.

80. Vervloet MG, Adema AY, Larsson TE, Massy ZA. The role of klotho on vascular calcification and endothelial function in chronic kidney disease. Semin Nephrol. 2014;34(6):578-85.

81. Temmar M, Liabeuf S, Renard C, Czernichow S, Esper NE, Shahapuni I, Presne C, Makdassi R, Andrejak M, Tribouilloy C, et al. Pulse wave velocity and vascular calcification at different stages of chronic kidney disease. J Hypertens. 2010;28(1):163-9.

82. Fox CS, Larson MG, Vasan RS, Guo CY, Parise H, Levy D, Leip EP, O'Donnell CJ, D'Agostino RB Sr, Benjamin EJ. Cross-sectional association of kidney function with valvular and annular calcification: the Framingham heart study. J Am Soc Nephrol. 2006;17(2):521-7.

83. London GM, Guerin AP, Marchais SJ, Metivier F, Pannier B, Adda H. Arterial media calcification in end-stage renal disease: impact on all-cause and cardiovascular mortality. Nephrol Dial Transplant. 2003;18(9):1731-40.

84. Schafer C, Heiss A, Schwarz A, Westenfeld R, Ketteler M, Floege J, MullerEsterl W, Schinke T, Jahnen-Dechent W. The serum protein alpha 2Heremans-Schmid glycoprotein/fetuin-A is a systemically acting inhibitor of ectopic calcification. J Clin Invest. 2003;112(3):357-66.

85. Bennett BJ, Scatena M, Kirk EA, Rattazzi M, Varon RM, Averill M, Schwartz SM, Giachelli CM, Rosenfeld ME. Osteoprotegerin inactivation accelerates advanced atherosclerotic lesion progression and calcification in older ApoE-/- mice. Arterioscler Thromb Vasc Biol. 2006;26(9):2117-24.

86. McCabe KM, Booth SL, Fu X, Shobeiri N, Pang JJ, Adams MA, Holden RM. Dietary vitamin $\mathrm{K}$ and therapeutic warfarin alter the susceptibility to vascular calcification in experimental chronic kidney disease. Kidney Int. 2013;83(5): $835-44$

87. O'Neill WC, Lomashvili KA, Malluche HH, Faugere MC, Riser BL. Treatment with pyrophosphate inhibits uremic vascular calcification. Kidney Int. 2011; 79(5):512-7.

88. Yamada S, Giachelli CM. Vascular calcification in CKD-MBD: Roles for phosphate, FGF23, and Klotho. Bone. 2017;100:87-93.
89. Paloian NJ, Giachelli CM. A current understanding of vascular calcification in CKD. Am J Physiol Renal Physiol. 2014;307(8):F891-900.

90. Tonelli M, Curhan G, Pfeffer M, Sacks F, Thadhani R, Melamed ML, Wiebe N, Muntner P. Relation between alkaline phosphatase, serum phosphate, and all-cause or cardiovascular mortality. Circulation. 2009;120(18):1784-92.

91. Block GA, Klassen PS, Lazarus JM, Ofsthun N, Lowrie EG, Chertow GM. Mineral metabolism, mortality, and morbidity in maintenance hemodialysis. J Am Soc Nephrol. 2004;15(8):2208-18.

92. Jono S, McKee MD, Murry CE, Shioi A, Nishizawa Y, Mori K, Morii H, Giachelli CM. Phosphate regulation of vascular smooth muscle cell calcification. Circ Res. 2000;87(7):E10-7.

93. Chavkin NW, Chia JJ, Crouthamel MH, Giachelli CM. Phosphate uptakeindependent signaling functions of the type III sodium-dependent phosphate transporter, PiT-1, in vascular smooth muscle cells. Exp Cell Res. 2015;333(1):39-48

94. Shanahan CM, Crouthamel MH, Kapustin A, Giachelli CM. Arterial calcification in chronic kidney disease: key roles for calcium and phosphate. Circ Res. 2011;109(6):697-711.

95. Zhang W, Xue D, Hu D, Xie T, Tao Y, Zhu T, Chen E, Pan Z. Secreted klotho protein attenuates osteogenic differentiation of human bone marrow mesenchymal stem cells in vitro via inactivation of the FGFR1/ERK signaling pathway. Growth factors. 2015;33(5-6):356-65.

96. Zhao Y, Zhao MM, Cai Y, Zheng MF, Sun WL, Zhang SY, Kong W, Gu J, Wang X, Xu MJ. Mammalian target of rapamycin signaling inhibition ameliorates vascular calcification via Klotho upregulation. Kidney Int. 2015; 88(4):711-21.

97. Hamano T. Klotho upregulation by rapamycin protects against vascular disease in CKD. Kidney Int. 2015;88(4):660-2.

98. Chang JR, Guo J, Wang Y, Hou YL, Lu WW, Zhang JS, Yu YR, Xu MJ, Liu XY, Wang XJ, et al. Intermedin1-53 attenuates vascular calcification in rats with chronic kidney disease by upregulation of alpha-Klotho. Kidney Int. 2016; 89(3):586-600

99. Hum JM, O'Bryan LM, Tatiparthi AK, Cass TA, Clinkenbeard EL, Cramer MS, Bhaskaran M, Johnson RL, Wilson JM, Smith RC, et al. Chronic Hyperphosphatemia and Vascular Calcification Are Reduced by Stable Delivery of Soluble Klotho. J Am Soc Nephrol. 2017;28(4):1162-74.

100. Cheng L, Zhang L, Yang J, Hao L. Activation of peroxisome proliferatoractivated receptor gamma inhibits vascular calcification by upregulating Klotho. Exp Ther Med. 2017;13(2):467-74.

101. Moe S, Drueke T, Cunningham J, Goodman W, Martin K, Olgaard K, Ott S, Sprague S, Lameire N, Eknoyan G. Definition, evaluation, and classification of renal osteodystrophy: a position statement from Kidney Disease: Improving Global Outcomes (KDIGO). Kidney Int. 2006;69(11):1945-53.

102. Fang Y, Ginsberg C, Sugatani T, Monier-Faugere MC, Malluche H, Hruska KA. Early chronic kidney disease-mineral bone disorder stimulates vascular calcification. Kidney Int. 2014;85(1):142-50.

103. Hruska KA, Seifert M, Sugatani T. Pathophysiology of the chronic kidney disease-mineral bone disorder. Curr Opin Nephrol Hypertens. 2015;24(4): 303-9.

104. Fang Y, Ginsberg C, Seifert M, Agapova O, Sugatani T, Register TC, Freedman Bl, Monier-Faugere MC, Malluche H, Hruska KA. CKD-induced wingless/integration 1 inhibitors and phosphorus cause the CKD-mineral and bone disorder. J Am Soc Nephrol. 2014;25(8):1760-73.

105. He W, Dai C, Li Y, Zeng G, Monga SP, Liu Y. Wnt/beta-catenin signaling promotes renal interstitial fibrosis. J Am Soc Nephrol. 2009;20(4):765-76.

106. Cejka D, Marculescu R, Kozakowski N, Plischke M, Reiter T, Gessl A, Haas M. Renal elimination of sclerostin increases with declining kidney function. J Clin Endocrinol Metab. 2014;99(1):248-55.

107. Pelletier S, Dubourg L, Carlier MC, Hadj-Aissa A, Fouque D. The relation between renal function and serum sclerostin in adult patients with CKD. Clin J Am Soc Nephrol. 2013;8(5):819-23.

108. Agapova OA, Fang Y, Sugatani T, Seifert ME, Hruska KA. Ligand trap for the activin type IIA receptor protects against vascular disease and renal fibrosis in mice with chronic kidney disease. Kidney Int. 2016;89(6):1231-43.

109. Sugatani T, Agapova OA, Fang Y, Berman AG, Wallace JM, Malluche HH, Faugere MC, Smith W, Sung V, Hruska KA. Ligand trap of the activin receptor type IIA inhibits osteoclast stimulation of bone remodeling in diabetic mice with chronic kidney disease. Kidney Int. 2017;91 (1):86-95.

110. Lin W, Li Y, Chen F, Yin S, Liu Z, Cao W. Klotho preservation via histone deacetylase inhibition attenuates chronic kidney disease-associated bone injury in mice. Sci Rep. 2017;7:46195. 
111. Zhang Q, Liu L, Lin W, Yin S, Duan A, Liu Z, Cao W. Rhein reverses Klotho repression via promoter demethylation and protects against kidney and bone injuries in mice with chronic kidney disease. Kidney Int. 2017;91(1):144-56.

112. Webster AC, Nagler EV, Morton RL, Masson P. Chronic Kidney Disease. Lancet. 2017;389(10075):1238-52.

113. Nogueira A, Pires MJ, Oliveira PA. Pathophysiological Mechanisms of Renal Fibrosis: A Review of Animal Models and Therapeutic Strategies. In Vivo. 2017;31(1):1-22

114. Liu Y. Cellular and molecular mechanisms of renal fibrosis. Nat Rev Nephrol. 2011;7(12):684-96

115. Meng XM, Nikolic-Paterson DJ, Lan HY. Inflammatory processes in renal fibrosis. Nat Rev Nephrol. 2014;10(9):493-503.

116. Vanhove T, Goldschmeding R, Kuypers D. Kidney Fibrosis: Origins and Interventions. Transplantation. 2017;101(4):713-26.

117. Gagliardini E, Benigni A. Role of anti-TGF-beta antibodies in the treatment of renal injury. Cytokine Growth Factor Rev. 2006;17(1-2):89-96.

118. Guan Q, Li S, Gao S, Chen H, Nguan CY, Du C. Reduction of chronic rejection of renal allografts by anti-transforming growth factor-beta antibody therapy in a rat model. Am J Physiol Renal Physiol. 2013;305(2):F199-207.

119. Ziyadeh FN, Hoffman BB, Han DC, Iglesias-De La Cruz MC, Hong SW, Isono M, Chen S, TA MG, Sharma K. Long-term prevention of renal insufficiency, excess matrix gene expression, and glomerular mesangial matrix expansion by treatment with monoclonal antitransforming growth factor-beta antibody in db/db diabetic mice. Proc Natl Acad Sci U S A. 2000;97(14):8015-20.

120. Border WA, Noble NA. Interactions of transforming growth factor-beta and angiotensin II in renal fibrosis. Hypertension. 1998;31(1 Pt 2):181-8.

121. Sharma K, Jin Y, Guo J, Ziyadeh FN. Neutralization of TGF-beta by anti-TGFbeta antibody attenuates kidney hypertrophy and the enhanced extracellular matrix gene expression in STZ-induced diabetic mice. Diabetes. 1996:45(4):522-30.

122. Kushibiki T, Nagata-Nakajima N, Sugai M, Shimizu A, Tabata Y. Delivery of plasmid DNA expressing small interference RNA for TGF-beta type II receptor by cationized gelatin to prevent interstitial renal fibrosis. J Control Release. 2005;105(3):318-31.

123. Trachtman H, Fervenza FC, Gipson DS, Heering P, Jayne DR, Peters H, Rota S, Remuzzi G, Rump LC, Sellin LK, et al. A phase 1, single-dose study of fresolimumab, an anti-TGF-beta antibody, in treatment-resistant primary focal segmental glomerulosclerosis. Kidney Int. 2011:79(11):1236-43.

124. Sugiura H, Yoshida T, Shiohira S, Kohei J, Mitobe M, Kurosu H, Kuro-o M, Nitta K, Tsuchiya K. Reduced Klotho expression level in kidney aggravates renal interstitial fibrosis. Am J Physiol Renal Physiol. 2012;302(10):F1252-64.

125. Doi S, Zou Y, Togao O, Pastor JV, John GB, Wang L, Shiizaki K, Gotschall R, Schiavi S, Yorioka N, et al. Klotho inhibits transforming growth factor-beta1 (TGF-beta1) signaling and suppresses renal fibrosis and cancer metastasis in mice. J Biol Chem. 2011;286(10):8655-65.

126. Fogo AB. Progression and potential regression of glomerulosclerosis. Kidney Int. 2001:59(2):804-19.

127. Branton MH, Kopp JB. TGF-beta and fibrosis. Microbes Infect. 1999;1(15): 1349-65.

128. Yang F, Chung AC, Huang XR, Lan HY. Angiotensin II induces connective tissue growth factor and collagen I expression via transforming growth factor-beta-dependent and -independent Smad pathways: the role of Smad3. Hypertension. 2009;54(4):877-84

129. Remuzzi G, Benigni A, Remuzzi A. Mechanisms of progression and regression of renal lesions of chronic nephropathies and diabetes. J Clin Invest. 2006;116(2):288-96.

130. Klahr S, Morrissey J. Obstructive nephropathy and renal fibrosis. Am J Physiol Renal Physiol. 2002;283(5):F861-75.

131. Mitani H, Ishizaka N, Aizawa T, Ohno M, Usui S, Suzuki T, Amaki T, Mori I, Nakamura $Y$, Sato $M$, et al. In vivo klotho gene transfer ameliorates angiotensin II-induced renal damage. Hypertension. 2002;39(4):838-43.

132. Zhou L, Li Y, Zhou D, Tan RJ, Liu Y. Loss of Klotho contributes to kidney injury by derepression of Wnt/beta-catenin signaling. J Am Soc Nephrol. 2013:24(5):771-85.

133. Huang JS, Chuang CT, Liu MH, Lin SH, Guh JY, Chuang LY. Klotho attenuates high glucose-induced fibronectin and cell hypertrophy via the ERK1/2-p38 kinase signaling pathway in renal interstitial fibroblasts. Mol Cell Endocrinol. 2014:390(1-2):45-53.

134. Guan X, Nie L, He T, Yang K, Xiao T, Wang S, Huang Y, Zhang J, Wang J, Sharma $\mathrm{K}$, et al. Klotho suppresses renal tubulo-interstitial fibrosis by controlling basic fibroblast growth factor-2 signalling. J Pathol. 2014;234(4):560-72.
135. Hu MC, Kuro-o M, Moe OW. The emerging role of Klotho in clinical nephrology. Nephrol Dial Transplant. 2012;27(7):2650-7.

136. Verbeke F, Van Biesen W, Vanholder R. The role of collagen metabolism in CKD-associated arterial senescence: underestimated and underappreciated. Nephrol Dial Transplant. 2011;26(9):2726-8.

137. Small DM, Bennett NC, Roy S, Gabrielli BG, Johnson DW, Gobe GC. Oxidative stress and cell senescence combine to cause maximal renal tubular epithelial cell dysfunction and loss in an in vitro model of kidney disease. Nephron Exp Nephrol. 2012;122(3-4):123-30.

138. Shimada T, Takeshita Y, Murohara T, Sasaki K, Egami K, Shintani S, Katsuda Y, Ikeda $\mathrm{H}$, Nabeshima $\mathrm{Y}$, Imaizumi T. Angiogenesis and vasculogenesis are impaired in the precocious-aging klotho mouse. Circulation. 2004;110(9):1148-55.

139. Chen Z, Qureshi AR, Ripsweden J, Wennberg L, Heimburger O, Lindholm B, Barany P, Haarhaus M, Brismar TB, Stenvinkel P. Vertebral bone density associates with coronary artery calcification and is an independent predictor of poor outcome in end-stage renal disease patients. Bone. 2016;92:50-7.

140. Takenaka T, Inoue T, Miyazaki T, Hayashi M, Suzuki H. Xeno-Klotho Inhibits Parathyroid Hormone Signaling. J Bone Miner Res. 2016;31(2):455-62.

141. Kuro OM. The FGF23 and Klotho system beyond mineral metabolism. Clin Exp Nephrol. 2017;21(Suppl 1):64-9.

142. Salanova Villanueva L, Sanchez Gonzalez C, Sanchez Tomero JA, Aguilera A Ortega Junco E. Bone mineral disorder in chronic kidney disease: Klotho and FGF23; cardiovascular implications. Nefrologia. 2016;36(4):368-75.

143. Shimamura Y, Hamada K, Inoue K, Ogata K, Ishihara M, Kagawa T, Inoue M, Fujimoto S, Ikebe M, Yuasa K, et al. Serum levels of soluble secreted alpha-Klotho are decreased in the early stages of chronic kidney disease, making it a probable novel biomarker for early diagnosis. Clin Exp Nephrol. 2012;16(5):722-9.

144. Rotondi S, Pasquali M, Tartaglione L, Muci ML, Mandanici G, Leonangeli C, Sales S, Farcomeni A, Mazzaferro S. Soluble alpha -Klotho Serum Levels in Chronic Kidney Disease. Int J Endocrinol. 2015;2015:872193.

145. Tan SJ, Smith ER, Holt SG, Hewitson TD, Toussaint ND. Soluble klotho may be a marker of phosphate reabsorption. Clin Kidney J. 2017:10(3):397-404.

146. Koh N, Fujimori T, Nishiguchi S, Tamori A, Shiomi S, Nakatani T, Sugimura K, Kishimoto T, Kinoshita S, Kuroki T, et al. Severely reduced production of klotho in human chronic renal failure kidney. Biochem Biophys Res Commun. 2001;280(4):1015-20.

147. Asai O, Nakatani K, Tanaka T, Sakan H, Imura A, Yoshimoto S, Samejima K, Yamaguchi Y, Matsui M, Akai Y, et al. Decreased renal alpha-Klotho expression in early diabetic nephropathy in humans and mice and its possible role in urinary calcium excretion. Kidney Int. 2012;81(6):539-47.

148. Kim HR, Nam BY, Kim DW, Kang MW, Han JH, Lee MJ, Shin DH, Doh FM, $\mathrm{Koo} \mathrm{HM}, \mathrm{Ko} \mathrm{Kl}$, et al. Circulating alpha-klotho levels in CKD and relationship to progression. Am J Kidney Dis. 2013;61(6):899-909.

149. Pavik I, Jaeger P, Ebner L, Wagner CA, Petzold K, Spichtig D, Poster D, Wuthrich RP, Russmann S, Serra AL. Secreted Klotho and FGF23 in chronic kidney disease Stage 1 to 5: a sequence suggested from a cross-sectional study. Nephrol Dial Transplant. 2013:28(2):352-9.

150. Wan M, Smith C, Shah V, Gullet A, Wells D, Rees L, Shroff R. Fibroblast growth factor 23 and soluble klotho in children with chronic kidney disease. Nephrol Dial Transplant. 2013;28(1):153-61.

151. Seiler S, Wen M, Roth HJ, Fehrenz M, Flugge F, Herath E, Weihrauch A, Fliser $D$, Heine GH. Plasma Klotho is not related to kidney function and does not predict adverse outcome in patients with chronic kidney disease. Kidney Int. 2013;83(1):121-8.

152. Seiler S, Rogacev KS, Roth HJ, Shafein P, Emrich I, Neuhaus S, Floege J, Fliser D, Heine GH. Associations of FGF-23 and sKlotho with cardiovascular outcomes among patients with CKD stages 2-4. Clin J Am Soc Nephrol. 2014;9(6):1049-58

153. Yamazaki Y, Imura A, Urakawa I, Shimada T, Murakami J, Aono Y, Hasegawa $H$, Yamashita T, Nakatani K, Saito Y, et al. Establishment of sandwich ELISA for soluble alpha-Klotho measurement: Age-dependent change of soluble alpha-Klotho levels in healthy subjects. Biochem Biophys Res Commun. 2010;398(3):513-8

154. Elghoroury EA, Fadel FI, Elshamaa MF, Kandil D, Salah DM, El-Sonbaty MM, Farouk H, Raafat M, Nasr S. Klotho G-395A gene polymorphism: impact on progression of end-stage renal disease and development of cardiovascular complications in children on dialysis. Pediatr Nephrol. 2018;33(6):1019-1027.

155. Sugiura H, Tsuchiya K, Nitta K. Circulating levels of soluble alpha-Klotho in patients with chronic kidney disease. Clin Exp Nephrol. 2011;15(5):795-6.

156. Akimoto T, Shiizaki K, Sugase T, Watanabe Y, Yoshizawa H, Otani N, Numata A, Takeshima E, Yamazaki T, Miki T, et al. The relationship between the 
soluble Klotho protein and the residual renal function among peritoneal dialysis patients. Clin Exp Nephrol. 2012;16(3):442-7.

157. Pavik I, Jaeger P, Ebner L, Poster D, Krauer F, Kistler AD, Rentsch K, Andreisek G, Wagner CA, Devuyst O, et al. Soluble klotho and autosomal dominant polycystic kidney disease. Clin J Am Soc Nephrol. 2012;7(2):248-57.

158. Devaraj S, Syed B, Chien A, Jialal I. Validation of an immunoassay for soluble Klotho protein: decreased levels in diabetes and increased levels in chronic kidney disease. Am J Clin Pathol. 2012;137(3):479-85.

159. Tan SJ, Cai MM. Is there a role for newer biomarkers in chronic kidney disease-mineral and bone disorder management? Nephrology (Carlton). 2017;22(Suppl 2):14-8

160. Heijboer AC, Blankenstein MA, Hoenderop J, de Borst MH, Vervloet MG. Laboratory aspects of circulating alpha-Klotho. Nephrol Dial Transplant. 2013;28(9):2283-7.

161. Kalaitzidis RG, Duni A, Siamopoulos KC. Klotho, the Holy Grail of the kidney: from salt sensitivity to chronic kidney disease. Int Urol Nephrol. 2016;48(10): 1657-66.

162. Hu MC. Klotho connects intermedin 1-53 to suppression of vascular calcification in chronic kidney disease. Kidney Int. 2016;89(3):534-7.

163. Takenaka T, Inoue T, Miyazaki T, Kobori H, Nishiyama A, Ishii N, Hayashi M, Suzuki $\mathrm{H}$. Klotho suppresses the renin-angiotensin system in adriamycin nephropathy. Nephrol Dial Transplant. 2017;32(5):791-800.

164. Azuma M, Koyama D, Kikuchi J, Yoshizawa H, Thasinas D, Shiizaki K, Kuro-o M, Furukawa Y, Kusano E. Promoter methylation confers kidney-specific expression of the Klotho gene. FASEB J. 2012;26(10):4264-74.

165. Zhang R, Zheng F. PPAR-gamma and aging: one link through klotho? Kidney Int. 2008;74(6):702-4.

166. Yoon HE, Ghee JY, Piao S, Song JH, Han DH, Kim S, Ohashi N, Kobori H, Kuro-o M, Yang CW. Angiotensin II blockade upregulates the expression of Klotho, the anti-ageing gene, in an experimental model of chronic cyclosporine nephropathy. Nephrol Dial Transplant. 2011;26(3):800-13.

167. Forster RE, Jurutka PW, Hsieh JC, Haussler CA, Lowmiller CL, Kaneko I, Haussler MR, Kerr Whitfield G. Vitamin D receptor controls expression of the anti-aging klotho gene in mouse and human renal cells. Biochem Biophys Res Commun. 2011;414(3):557-62.

168. Ritter CS, Zhang S, Delmez J, Finch JL, Slatopolsky E. Differential expression and regulation of Klotho by paricalcitol in the kidney, parathyroid. and aorta of uremic rats. Kidney Int. 2015;87(6):1141-52.

169. Shiraki-lida T, lida A, Nabeshima Y, Anazawa H, Nishikawa S, Noda M, Kuro-o M. Improvement of multiple pathophysiological phenotypes of klotho (k//kl) mice by adenovirus-mediated expression of the klotho gene. J Gene Med. 2000;2(4):233-42.

170. Wang Y, Sun Z. Antiaging gene Klotho regulates endothelin-1 levels and endothelin receptor subtype B expression in kidneys of spontaneously hypertensive rats. J Hypertens. 2014;32(8):1629-36 discussion 1636.

Ready to submit your research? Choose BMC and benefit from:

- fast, convenient online submission

- thorough peer review by experienced researchers in your field

- rapid publication on acceptance

- support for research data, including large and complex data types

- gold Open Access which fosters wider collaboration and increased citations

- maximum visibility for your research: over $100 \mathrm{M}$ website views per year

At $\mathrm{BMC}$, research is always in progress.

Learn more biomedcentral.com/submissions 